\title{
Willingness to adopt an e-payment system to increase the effectiveness of the budget disbursement in the public sector in Indonesia
}

\author{
Yanuar E. Restianto \\ Jenderal Soedirman University, Indonesia \\ Imam Ghozali \\ Agus Purwanto \\ Indira Januarti \\ Diponegoro University, Indonesia
}

\begin{abstract}
Keywords
e-payment, public sector, effectiveness government budget disbursement, technology acceptance model.
\end{abstract}

\begin{abstract}
The main objective of e-payment system development in government agencies in Indonesia is to overcome problems arising in financial management, such as frequent occurrences of delayed payment, incomplete and inaccurate documents, financial information not being punctual, human error and other technical problems. This research aims to analyze the acceptance of e-payment system in Indonesian government institution using Technology Acceptance Model (TAM) approach. This research also tries to find answers as to whether the adoption of an e-payment system has a positive impact on effectiveness of the government budget disbursement. This research has a valuable contribution to make to the Indonesian government which is considering adoption of an e-payment system in all government institutions. However, the e-payment system adoption needs a transitional process. This condition is in line with a statement made by Compeau and Higgins (1995), who found that a critical stage in the application of an information technology system is the condition in which the presence of a system is received or rejected by the potential user. Data in this research was obtained from a survey administered to users of an e-payment system at one of the universities in Indonesia. The research respondents consist of 261 users of e-payment systems.

This research data collected using the online questionnaire of e-payment system users. The data analysis employed the structural equation models. The findings of this study indicate that the perceived usefulness is an important factor which influences e-payment system acceptance; however, perceived ease of use has no influence on individual attitude because the e-payment system implementation in our study was mandatory. So, all employees had an obligation to run the system, although some of them may have experienced difficulties with this new system.
\end{abstract}

Corresponding author: Yanuar E. Restianto

Email addresses for corresponding author: yan_restianto@yahoo.com

First submission received: $20^{\text {th }}$ February 2018

Revised submission received: $29^{\text {th }}$ April 2018

Accepted: 22nd May 2018

Introduction

Information technology always develops in line with developments in human civilization. Development of information technologies covers the development of information technology infrastructure, such as hardware, software, technology data storage, and communication technology (Laudon, 2012). One part of this infrastructure is the B2C (Business to Consumer) application which is currently used in many electronic trading or e-commerce enterprises. An important component in conducting transactions is an electronic payment system (e-payment). E-payment is a system that provides tools for payment services or goods made via the Internet. An organization usually has a partnership with various financial institutions or banks to do e-payment, therefore the transactions can be done in real time and anywhere in accordance with their needs. There are many benefits in using epayment and these include: speeding up the process of transactions; the parties involved in the process of 
the transactions can transfer and receive money anytime and anywhere; e-payment also supports the movement of green technology wherein use of paper can be reduced.

The implementation of e-payment in the public sector, especially in government agencies in Indonesia, has rarely been implemented. The issuing of Act number 11/2008 (which focuses on information and electronic transactions) and which was then followed by the issuance of several regulations related to state financial management (allowing the use of electronic transactions), was a milestone in adopting the use of an electronic expenditure and disbursement system. The main objective of e-payment system development in government agencies in Indonesia is to overcome problems arising in financial management, such as frequent occurrences of delayed payment, incomplete and inaccurate documents, financial information not being punctual, human error and other technical problems. One of the factors driving the use of e-payment in government agencies is improving of satisfaction with the joint needs through improvement in the service quality.

In many research studies, a model has been used that describes the level of technological information - this model is the Technology Acceptance Model (TAM). Hence, this research is motivated to analyze the adoption of an e-payment system in government agencies in Indonesia using the Technology Acceptance Model (TAM) approach. Venkatesh and Davis (2000) stated that so far TAM is a concept that is considered to be relatively good in clarifying the behavior of users of a new information technology system. The main objective of TAM, according to Davis (1989), is giving an account of the determination of the computer in general and giving a description of the behavior and attitude of users in a given population. TAM has also been empirically proven to explain $40 \%$ of the intensions and behavior of users (Venkatesh and Davis, 2000). TAM is a model that describes how users of the technology receive and use the technology.

In general, research on revenue generated through information technology and which is based on the Technology Acceptance Model (TAM) that was introduced by Davis (1989), indicates that acceptance of technology by individuals is determined by two factors: the first factor is perceived usefulness, which is defined as the extent to which someone knows how to use systems to improve their performance; secondly, there is perceived ease of use, which is defined as the extent to which someone is sure that the use of a system is easy.

This research has a valuable contribution to make to the Indonesian government which is considering adoption of an e-payment system in all government institutions. However, the e-payment system adoption needs a transitional process. This condition is in line with a statement made by Compeau and Higgins (1995), who found that a critical stage in the application of an information technology system is the condition in which the presence of a system is received or rejected by the potential user. Different perceptions exist about the benefits and ease of use of the new system to be operated by potential users. Difficulties in the implementation of a new system are caused by employees needing time to adapt to the new system. To support this argument, Davis et al. (1989) found that system information is not able to increase organisational performance when not in use. The impact of the increase in performance is also not felt if the information system is rejected by the user (Davis, 1993), and there is no intention from the user to use it (Davis, 1989). Therefore, an information system is able to run well and achieve goals efficiently and effectively and if admitted by users. Hence, this research also tries to find answers as to whether the adoption of an e-payment system has a positive impact on effectiveness of the government budget disbursement.

\section{Literature Review \\ Electronic Payment System}

Electronic payment systems have been utilised in much of the banking sector as well as in the business sector, especially for the transfer of large sums of money. The Westminster Bank first installed an Automated Teller Machine (ATM) at Victoria in the 1960's. According to the Federal Financial Institutions Examination Council (2010), electronic payment was a new payment practice for the retail sector in which a merchant takes information on payments for goods and services and puts this information in an electronic template which then created electronic files to be processed through the bank clearing.

A lot of technology development that occurs after four decades the emergence of e-payment, that enables the expansion of a system of electronic payment itself, including social activities that require the 
system. As a consequence, this change has affected the definition of e-payment, because its development is highly influenced by the need for the system. Several studies have tried to define e-payment; an online payment has been understood to indicate that a vendor has conducted checks on the payment which has been taken from buyers through a bank before a vendor serving the purchase of the buyer (Al-Fayoumi et al., 2010). However, a common understanding of e-payment is that it is just a payment that is conducted electronically and online.

According to Sumanjeet (2009), in the most common form, the term electronic payment covers payment for business, banks and public services of citizens or businesses, which have been conducted through a telecommunications or electronic network supported by modern technology. According to some previous notions, e-payment can be defined as a payment system that can be used by parties, such as banks, businesses (vendor or consumers) and social actors, and is conducted online through rapidly developing information technology systems.

\section{Electronic Payment System Process}

According to Al-Fayoumi et al. (2010), the electronic payment process is carried out by users, the merchant, and the bank. Users by the use the money electronics (e-currency) from bank in the implementation of the e-payment to do the transaction, whether it is buying goods or paying for services. The role of the trader is providing goods, services or information offered and sold to the user (the customer), while the bank is believed to mediate and to ease the transaction between users and traders. In the electronic payment process, money is kept, processed, and accepted in the form of digital information and the process of recording initialized through electronic payment tools.

Based on the understanding above, it can be concluded that all process in a system of electronic payment conducted electronically, with money that has been deposited in advance by the users of or subscribers to the bank, and processed by the bank and accepted in the form of digital information by the merchant or the recipients; the process of recording the transaction is initialized via an electronic payment system.

\section{Technology Acceptance Model (TAM)}

TAM, which was introduced by Davis in 1986, is an adaptation of the Theory of Reasoned Action (TRA) developed by Fishbein and Ajzen (1975). TAM is a theory developed especially for modeling users' acceptance of system information. According to Davis (1989), the main objective of TAM is to give a basic external factors of faith, attitudes and the purpose of users. TAM explains that two individual factors are perceived usefulness and perceived ease of use, and these have a significant influence on information system acceptance behavior. Generally, TAM describes two factors that have a strong influence on technology integration. The first factor is the perception of users concerning the ease of use of the technology; the second factor is the perception of users as to the usefulness of the technology. These two factors affect users' willingness to use the technology, which later will affect the use of the technology which was actually used (Davis, 1989). TAM has two main variables, namely perceived usefulness and perceived ease of use, with both being similar in predicting acceptance of the computer technology (acceptance of IT) by the user. Reactions and perceptions of users will affect the way they accept new information technology. One of the factors that might affect users' perceptions concerns the usefulness and the ease of use of the information technology as an act of a reasonable job in terms of the use of information technology. Perceived usefulness and ease of use can be reasons for a person to see the benefit and ease of use of the information technology.

Yi and Hwang (2003) stated that TAM has received much attention from researchers and practitioners as a simple model that is robust in explaining and predicting the intentions and behaviors of users. TAM has two aspects - i.e. 1) the commonly called beliefs consisting of perceived usefulness and perceived ease of use; 2) attitude and behavioral intention to use and usage behavior (Straub, Limayen, Evaristo, 1995). The following figure pictures the relationship between the components of TAM: 


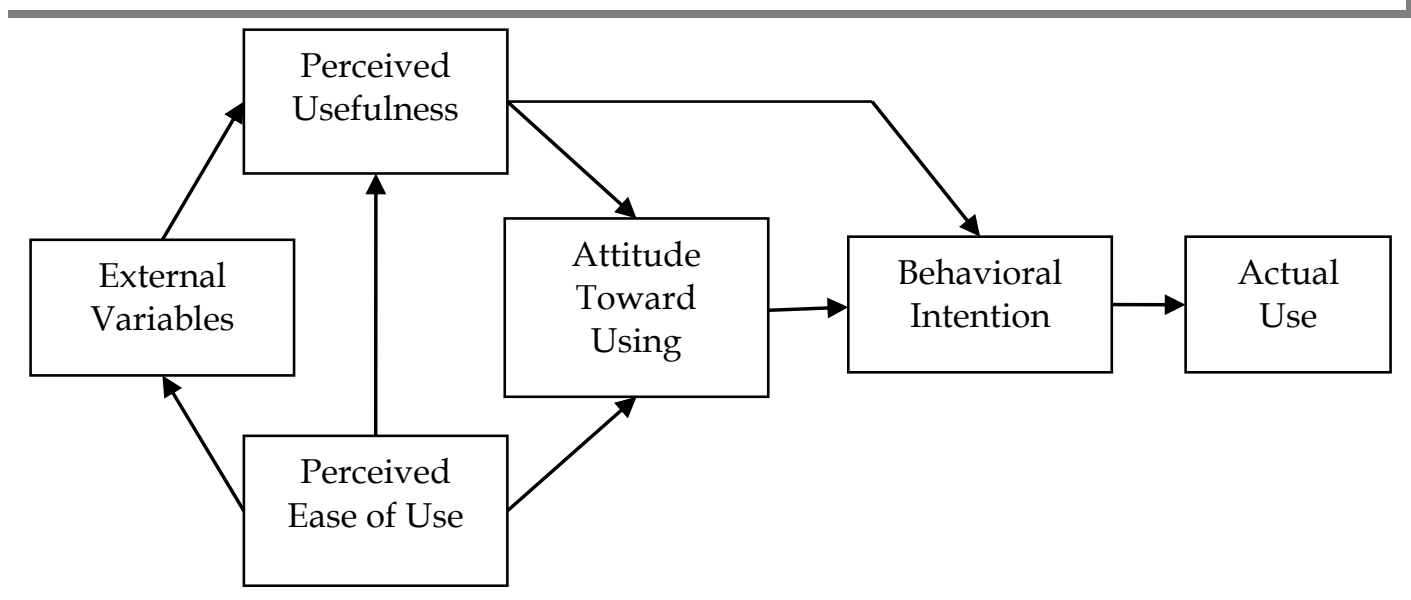

Figure 1. Technology Acceptance Model

TAM provides a framework which can aid investigation of the impact of external variables on individual intention to accept new information technology. The utilization of the system and the objectives in TAM describe the relationship which indicates the purpose of the individual to act positively. Perception of benefits and the objectives of the system are based on the basic idea that the purpose of an organization is to improve its performance.

\section{Effectiveness Theory}

A general definition of effectiveness is that a goal or target has been achieved, and this has a correlation with efficiency, although there is a difference between them. 'Effectiveness' places more emphasis on the results, while 'efficiency' focuses more on how to achieve the result by comparing input and output. The terms effective and efficient are two interlocking terms, and must be used in any attempt to achieve a goal. Mardiasmo (2009) stated that effectiveness is an indicator of an organization achieving its goals. If an organization achieves its objectives, the organisation is said to have been working effectively. The effectiveness of only see whether a program or activity has reached its intended purpose. Rotchanakitumnuai (2013) found that e-government process has a positive effect on good governance practice, increasing cost and effectiveness and accountability, and decreasing collusion among the vendors.

\section{Research Model and Hypothesis Development}

Davis (1989) defines perceived ease of use as an individual holding the belief that use of the system will enable them to avoid obstacles. Davis (1989) concluded that perceived ease of use has an impact on perceived usefulness. Carter (2008) holds a similar opinion to Davis (1989), stating that perceived ease of use has a significant impact on intention to use through perceived usefulness. Lee (2009) and Aboelmaged (2009) also have the same opinion, stating that the factor that influences adoption of a system by the end-user is perceived ease of use through perceived usefulness. The relationship between perceived ease of use and perceived usefulness of the information system has also been validated in the context of online technology (Gefen \& Straub, 2003; Gefen et al., 2003; McCloskey, 2006; McKechnie et al., 2006; Morosan \& Jeong, 2008). Based on this argument, the first proposed hypothesis is:

$\mathrm{H}_{1}$ : Perceived ease of use has a positive influence on perceived usefulness of the e-payment system.

Carter (2008), Davis (1989) and Aboelmaged (2009) stated that perceived ease of use will affect users' behavior in terms of use of the system. This is consistent with the opinion of Ajzen and Fishbein (1980), who stated that attitude to the use of the system is affected by perceived usefulness, which will then determine the behavior of users. Some previous studies have also shown that ease of use of is its main attributes of application e-business as e-commerce (Chen et al., 2002; Heijden et al., 2003), online banking (Guriting dan Ndubisi, 2006), and mobile commerce (Lin dan Wang, 2005; Luarn dan Lin, 2005). Thus, the second hypothesis is developed as follows:

$\mathrm{H}_{2}$ : Perceived ease of use has a positive influence on attitude toward using the e-payment system. 
Davis (1989) stated that perceived usefulness is where someone believes that the systems will be able to improve their performance. Perceived usefulness and perceived ease of use will affect the attitude of the person using the system. A similar opinion is held by Carter (2008), who found that perceived usefulness had a significant impact on users' intention to use. Perceived usefulness is also a highly important variable for predicting information system adoption. Perceived usefulness is partially able to explain variance in intention to use. The influence of the benefits of use that is realised in the attitudes of individuals has been proven in many studies (e.g. see Chen et al., 2002: Cheung and Liao, 2003; Gribbins et al., 2003; Heijden et al., 2003; Liao \& Cheung, 2001). Based on this explanation, the third hypothesis is as follows:

\section{$\mathrm{H}_{3}$ : Perceived usefulness has a positive influence on attitude toward using the e-payment system.}

One of the behavioural indicators of technology acceptance is perceived usefulness (Davis, 1989). Davis (1989) also indicated that perceived usefulness has a positive influence on an individual's intention to use technology. Carter (2008) stated that perceived usefulness, trust, previous use and perceived ease of use had a significant impact on intention to use the information system. Perceived usefulness is the most important factor for predicting adoption of an e-government system. Lee (2009) and Aboelmaged (2009) also concluded that one of the variables affecting adoption of a system by the end-user is perceived usefulness. Perceived usefulness can lead to behavioral intention, which indicates that the intention of the individual to use the technology will be strong regardless of their attitude to the technology. Based on this statement and the conclusions given above, the fourth hypothesis is developed as follows:

\section{$\mathrm{H}_{4}$ : Perceived usefulness has a positive influence on behavioral intention to use the e-payment system.}

The intention to do something is formed based on individual behavior and subjective norms (Fishbein \& Ajzen, 1975; Ajzen \& Fishbein, 1980). The first important factor is behavior - this reflects a person's beliefs that their behavior will produce something favorable or unfavorable. The attitudes of individuals directly and significantly affect their intention to use an e-business application (George, 2002; Gribbins et al., 2003). George (2002) also found a strong relationship between individual behavior and the intention to use an online purchasing system. Gribbins et al. (2003) studied users' wireless technology use and stated that there was a relationship between attitude and intention to use mobile commerce. The fifth hypothesis was thus developed as follows:

$\mathrm{H}_{5}$ : Attitude to use has a positive influence on behavioral intention to use an e-payment system.

Davis (1989) indicates that the main objective of TAM is to provide a basis for investigating the external variables of faith, attitudes and the purpose behind individuals' use of an information system. The variables affect willingness to use the technology, which then affects the use of the technology (Davis, 1989). This is consistent with the concept of TRA (Fishbein, 1980), which concludes that the behavior of users will, in the end, affect intention to use the information system. Based on this, therefore, hypothesis 6 is developed as follows:

\section{$\mathrm{H}_{6}$ : Behavioral intention has a positive influence on actual use of an e-payment system.}

Mardiasmo (2009) stated that effectiveness is an indicator of an organization's level of success in reaching an objective. The way to effectively achieve organizational goals is by using a suitable information system. Curristine et al. (2007) stated that the performance of the information system, which is associated with budgeting, can improve the control of expenditures in public sector management. The main focus is on how to improve the quality of information in budget decision-making and should be associated with resources. The quality of information will be influenced by the quality of the information system. Thus, a good information system will produce accurate information which has an impact on improving controls or increasing the effectiveness of the budget spending. Based on this explanation, hypothesis 7 is developed as follows:

$\mathrm{H}_{7}$ : Actual use has a positive influence on effectiveness of budget disbursement. 
Figure 2 below represents the research model in this research study. The variables measured in this research refer to the instruments of Venkatesh and Davis (1996, 2000), Wu and Chen (2005), Aboelmaged (2009), and Cheng et al. (2006). Figure 2 shows six variables that will be investigated, and the indicators used.

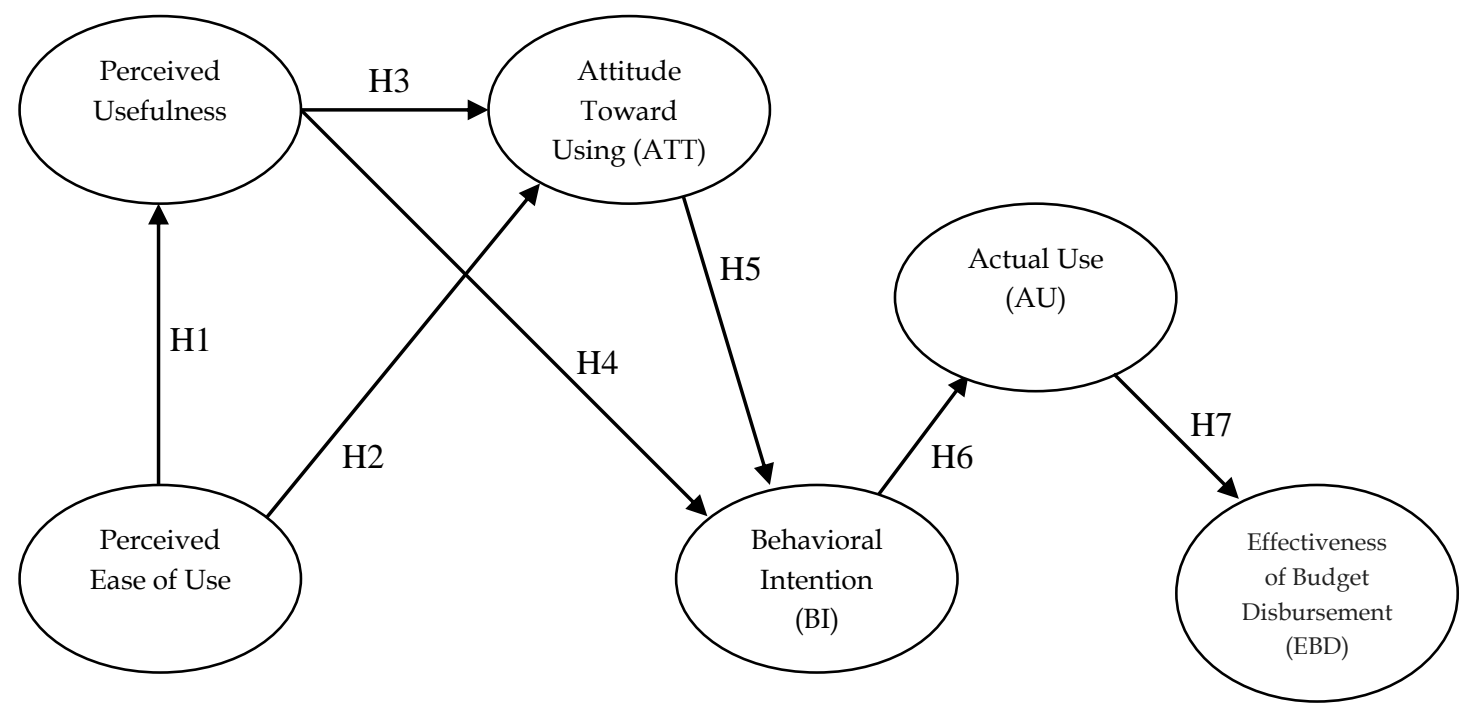

Figure 2. Research model

\section{Research Method}

This research aims to analyze the implementation of an e-payment system in one of the government institutions in Indonesia. The TAM model has been used to explain e-payment system acceptance by adding the effectiveness of the budget disbursement as a variable. Data in this research was obtained from a survey administered to users of an e-payment system at one of the universities in Indonesia. This research used a clustered sampling method by sending the questionnaire to 440 users of the e-payment system. Of this number, 261 questionnaires were collected and accurately completed; these were then processed for further analysis. The questionnaire was designed to answer questions about the determinant use of the e-payment system; the relationship between the use of the e-payment system and the effectiveness of the budget disbursement was then later tested.

To improve the effectiveness of the budget disbursement, all respondents were asked to assess each variable so that their intention to participate in the use of the e-payment system could be known. The answer is considered use respondents scale likert 5 points, starting from 1 (strongly disagree) to 5 (total agree). The questionnaire consists of 27 items, as demonstrated in Table 1 below.

Table 1. Operation Variable

\begin{tabular}{lll}
\hline Variable & Notation & Description \\
\hline PU & PU1 & Make work faster \\
& PU2 & Can improve performance \\
& PU3 & Can increase productivity \\
& PU4 & Work more effective \\
& PU5 & Facilitate work \\
PEOU & PU6 & Beneficial to support work \\
& PEoU1 & Easy to learn and does not require great effort \\
& PEoU2 & Can be easily controlled \\
& PEoU3 & Flexible in use \\
& PEoU4 & Easy to be skillful \\
ATT & PEoU5 & Easy to use \\
& ATT1 & Good system \\
& ATT2 & The policy of system \\
& ATT3 & Happy after the system \\
\hline
\end{tabular}

www.jbrmr.com A Journal of the Academy of Business and Retail Management (ABRM) 


\begin{tabular}{lll}
\hline Variable & Notation & Description \\
\hline \multirow{3}{*}{ BI } & ATT4 & Get advantages if use the system \\
& ATT5 & An assessment of system \\
& BI1 & Will always use the for all payment transaction \\
AU & BI2 & Use the system continuously \\
& AU1 & Will suggest other people use the system \\
EBD & AU2 & Always use system for all payment transactions \\
& EBD1 & Advise others to use the system \\
& EBD2 & Assessment of the effectiveness of budget disbursement \\
& EBD3 & The budget disbursement plan fulfilled \\
& EBD4 & The disbursement of punctuality budget better \\
& EBD5 & The speed of the budget disbursement was better \\
& EBD6 & Procedure work more concise
\end{tabular}

\section{Analysis}

To test the six variables, this research used seven hypotheses. All the hypotheses were analyzed using Structural Equation Modeling (SEM) to simultaneously test the influence of each independent variable on the dependent variables. Figure 3 displays the coefficient for each variable to other variables. SEM used squared multiple correlations as model evaluation for dependent variables and standardized regression weights for independent variables. $C R$ ( $t$ value) was used for measuring the path coefficient. The P-value was obtained from the results of the analysis using AMOS software.

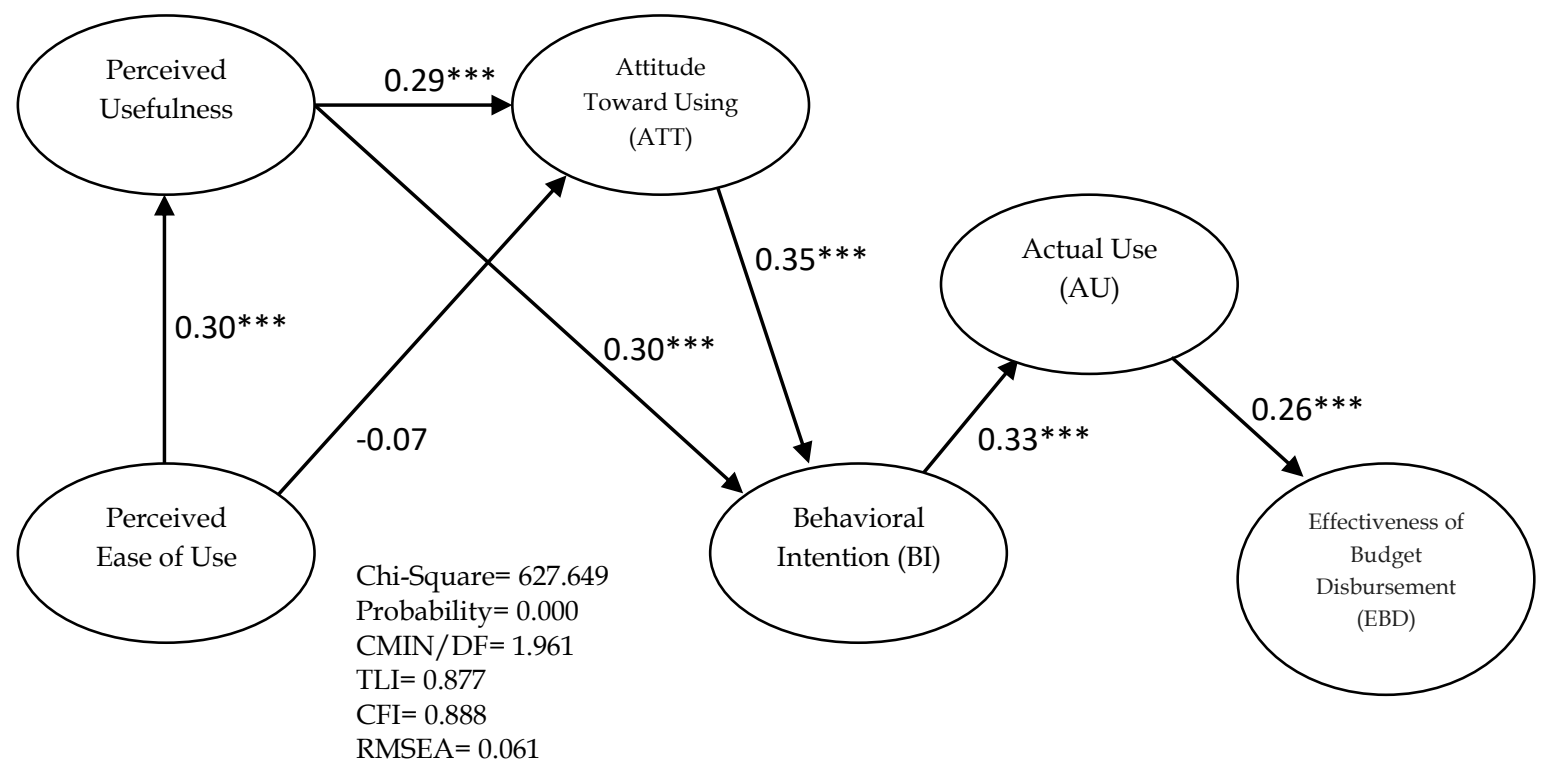

Figure 3. Full model the the relationship between e-payment system adoption and the effectiveness of budget disbursement

The results of the testing of the submitted research hypotheses can be seen in Table 2 .

Table 2. Beta, C.R., and P Value

\begin{tabular}{|c|c|c|c|c|c|}
\hline \multicolumn{3}{|c|}{$\begin{array}{l}\text { The Relationship between } \\
\text { Construct }\end{array}$} & \multirow{2}{*}{$\begin{array}{c}\text { Beta } \\
.298\end{array}$} & \multirow{2}{*}{$\begin{array}{l}\text { C.R. } \\
4.257\end{array}$} & \multirow{2}{*}{$\begin{array}{l}\mathrm{P} \\
* * *\end{array}$} \\
\hline PEoU & $\rightarrow$ & PU & & & \\
\hline PEoU & $\rightarrow$ & ATT & -.072 & -0.967 & .334 \\
\hline PU & $\rightarrow$ & ATT & .287 & 3.750 & $* * *$ \\
\hline ATT & $\rightarrow$ & BI & .354 & 4.593 & $* * *$ \\
\hline PU & $\rightarrow$ & BI & .304 & 4.265 & $* * *$ \\
\hline BI & $\rightarrow$ & $\mathrm{AU}$ & .330 & 4.541 & $* * *$ \\
\hline
\end{tabular}




\begin{tabular}{|c|c|c|c|}
\hline $\begin{array}{l}\text { The Relationship between } \\
\text { Construct }\end{array}$ & Beta & C.R. & $\mathrm{P}$ \\
\hline $\begin{array}{lll}\mathrm{AU} & \rightarrow & \mathrm{EBD}\end{array}$ & .261 & 3.515 & *** \\
\hline
\end{tabular}

The first hypothesis proposed that perceived ease of use has a positive impact on perceived usefulness of the e-payment system. Table 2 shows perceived ease of use and perceived usefulness having the coefficients beta 0.298 and C.R. 4.257 with P-value $<0.05$. This result indicates that the perceived ease of use variable has a significant impact on perceived usefulness. So, the first hypothesis which stated that perceived ease of use has a positive impact on perceived usefulness of the e-payment system is supported statistically.

The second hypothesis in this research stated that perceived ease of use has a positive impact on attitude to using the e-payment system. Table 2 shows that the perceived ease of use and attitude to using the e-payment system have a coefficient of beta -0.072 and C.R. -0.967 with P-value $>0.05$. This indicates that the perceived ease of use variable has no impact on the attitude variable. The second hypothesis, which states that perceived ease of use has a positive impact on attitude to using the e-payment system, is not supported in this research.

The third hypothesis stated that perceived usefulness has a positive impact on attitude to using the e-payment system. Table 2 shows that perceived usefulness and attitude to using the e-payment system have coefficients beta 0.287 and C.R. 3.750 with P-value $<0.05$. This indicates that the perceived usefulness variable has a significant impact on the attitude variable. The third hypothesis, which states that perceived usefulness has a positive impact on attitude to using the e-payment system is supported statistically in this research.

The fourth hypothesis in this research states that perceived usefulness has a positive impact on behavioral intention to use the e-payment system. Table 2 shows that perceived usefulness and behavioral intention to use the e-payment system have coefficients beta 0.304 and C.R. 4.265 with P-value $<0.05$. This means that the perceived usefulness variable has a significant impact on behavioral intention. The fourth hypothesis, which states that perceived usefulness has a positive impact on behavioral intention to use the e-payment system, is supported statistically.

The fifth hypothesis in this research states that the attitude variable has a positive impact on behavioral intention to use the e-payment system. Table 2 shows that attitude to using the system and behavioral intention to use have coefficients beta 0.354 and C.R. 4.593 with P-value $<0.05$. This indicates that attitude toward has a significant impact on behavioral intention. The fifth hypothesis, which states that the attitude variable has a positive impact on behavioral intention to use the e-payment system, is supported statistically.

The sixth hypothesis stated that behavioral intention has a positive impact on actual use of the epayment system. The behavioral intention variable and actual use have coefficients beta 0.330 and C.R. 4.541 with P-value $<0.05$ (Table 2). This indicates that behavioral intention has a significant impact on actual use of the e-payment system. The sixth hypothesis was supported statistically.

The seventh hypothesis stated that actual use has a positive impact on the effectiveness of the budget disbursement. Table 2 displays that actual use and effectiveness of the budget disbursement have coefficients beta 0.261 and C.R. 3.515 with P-value $<0.05$. This means that actual use has a significant impact on the effectiveness of the budget disbursement. Thus, the seventh hypothesis is supported statistically.

\section{Discussion}

This research indicates that perceived ease of use has a positive influence on perceived usefulness of the e-payment system. This means that perceived ease of use of the e-payment system operated by an individual would have a positive impact on system advantages. An easy e-payment system operated by an individual will have benefits for an e-payment system. This result is consistent with the findings of Davis (1989), Carter (2008), Lee and Lee (2009), and Aboelmaged (2009) who find that the factor that influences system adoption by the end-user is perceived ease of use through perceived usefulness. 
However, this result indicates the absence of the influence of perceived ease of use on individuals' attitudes to the use of an e-payment system. This finding is contrary to the opinion of Davis (1989), Carter (2008), and Aboelmaged (2009), who found that perceived ease of use will affect attitudes to the use of information systems. There is a gap in this result, compared with previous studies, which might have been caused by the fact that the e-payment system in this university is mandatory. Therefore, individuals are obliged to use this information system, so the e-payment system has no effect on the attitudes of individuals to the use of the e-payment system. This study discovered that the attitudes of individuals to the use of the e-payment system was influenced by the benefit that was perceived by these individuals. This finding supports the previous findings of Davis (1989), Carter (2008), and Aboelmaged (2009), who found that advantages will affect the use of the system.

The results of the analysis also show the presence of the influence of perceived usefulness of the epayment system and the attitudes of individuals to e-payment and their intention to use the e-payment system. This supports the opinion of Davis (1989) and Carter (2008), who found that perceived usefulness has a positive influence on an individual's intention to use the e-payment system. The same conclusion was also given by Lee and Lee (2009) and Aboelmaged (2009), who found that the most important variable affecting adoption of a system by the end-user is perceived usefulness. This research is also in line with opinions stating that the attitudes of individuals directly and significantly affect intention to use e-business applications (George, 2002; Gribbins et al., 2003).

We also found that actual use of the e-payment system is influenced by the intention of the individual to use it. The higher intention of someone to use the e-payment system will increase the frequency of utilization of the e-payment system. This outcome is consistent with a conclusion given by Davis (1989), who states that willingness to use the technology will affect the use of the technology. This is also consistent with the concept of TRA (Ajzen \& Fishbein, 1980), which indicates how users' behaviors will affect their intention to use the information system.

A new and interesting finding from this study is that the use of an e-payment system is actually capable of affecting the effectiveness of the process of budget disbursement. This is in line with one of the aims of the adoption of information systems, namely for enhancing the efficiency and effectiveness of the organization. This corresponds with the statement by Curristine et al. (2007) that the performance of the information system is associated with the budgeting process and will be able to improve the control of expenditures of public sector management. One of the things that affects the use of the budget is the quality of the information. The quality of information will be influenced by the quality of the system from which they get the information. Thus, a good information system will produce high quality information, and then could improve controls or increase the effectiveness of budget expenditures. There is still limited research that has determined information system acceptance related to the measurement of the effectiveness and efficiency of an organization. This research is successful in filling the research gap on the information system-based TAM with the effectiveness of information system to support was budget disbursement on government institution in Indonesia.

\section{Conclusion}

This study used TAM as a framework to investigate the impact of the TAM variable on acceptance of new information technology. Perceived usefulness is an important factor which influences e-payment system acceptance; however, peceived ease of use has no influence on individual attitude because the epayment system implementation in our study was mandatory. So, all employees had an obligation to run the system, although some of them may have experienced difficulties with this new system.

This study has the limitation of only using a public university as a research sample. Further research should include more government institutions in the sample, and consider the educational level of the system user. Unified Theory of Acceptance and Use of Technology (UTAUT) should be considered to explain adoption of e-payment system on the further studies. UTAUT is developed through integration of several dominant theories to examine user intention and behaviour.

\section{References}

Aboelmaged, M.G. 2009. Predicting E-Procurment Adoption in A Developing Country: An Empirical Integration of Technology Acceptance Model and Theory of Planned Behaviour. Industrial Management E Data Systems, 110, 329-414. 
Ajzen, I. dan Fishbein, M. 1980. Understanding Attitudes and Predicting Social Behavior. Prentice-Hall, Englewood Cliffs, NJ.

Al-Fayoumi, M., Aboud, S., and Al-Fayoumi, M. 2010. Practical E-Payment Scheme. International Journal of Computer Science, 7, 18-23.

Carter, Lemuria. 2008. E-Government Diffusion: a Comparison of Adoption Constructs. Transforming Government: People, Process and Policy, 2, 147-161.

Chen, L., Gillenson, M. dan Sherrell, D. 2002. Enticing Online Consumers: an Extended Technology Acceptance Perspective. Information \& Management, 39, 705-19.

Cheng, T., Lam, D. and Yeung, A. 2006. Adoption of internet banking: an empirical study in Hong Kong. Decision Support Systems, 42, 1558-72.

Cheung, M. dan Liao, Z. 2003. Supply-Side Hurdles in Internet B2C e-Commerce: an Empirical Investigation. IEEE Transactions on Engineering Management, 50, 458-69.

Compeau, D. R., \& Higgins, C. A. 1995. Computer self-efficacy: Development of a measure and initial test. MIS Quarterly, 19, 189-211.

Curristine, T., Lonti, Z., and Joumard, I. 2007. Improving Public Sector Efficiency: Challenges and Opportunities. OECD Journal on Budgeting, 7, 1-41.

Davis, F.D. 1989. Perceived Usefulness, Perceived Ease of Use, and User Acceptance of Information Technology. MIS Quarterly, 13, 319-340.

Davis, F.D. 1993. User Acceptance of Information Technology: System Characteristics, User Perceptions and Behavioral Impacts. International Journal Man-Machine Studies, 38, 475-487.

Davis, F.D., Bagozzi, R.P. dan Warshaw, P.R. 1989. User Acceptance of Computer Technology: a Comparison of Two Theoretical Models. Management Science, 35, 982-1003.

Fishbein, M., dan Ajzen, I. 1975. Belief, Attitude, Intention and Behaviour: an introduction to theory and research. USA: Addison-Wesley Publishing Company.

Gefen, D. dan Straub, D. 2003. Managing user trust in B2C e-services, E-Service Journal, 2, 7-24.

Gefen, D., Karahanna, E., dan Straub, D. 2003. Trust and TAM in online shopping: an integrated model. MIS Quarterly, 27, 51-90.

George, J. 2002. Influences on the intent to make internet purchases. Internet Research, 12, 165-80.

Gribbins, M., Shaw, M. and Gebauer, J. 2003. An investigation into employees acceptance of integrating mobile commerce into organizational processes. Proceedings of the 9th Americas Conference on Information Systems, Tampa, FL, 77-87.

Guriting, P. and Ndubisi, A. 2006. Borneo online banking: evaluating customer perceptions and behavioral intention. Management Research News, 29, 6-15.

Heijden, H., Verhagen, T. dan Creemers, M. 2003. Understanding online purchase intentions: contributions from technology and trust perspectives. European Journal of Information Systems, 12, 41-8.

Laudon, Kenneth C. \& Jane P. Laudon. 2012. Management Information System. 12th Edition. Prentice Hall, New York.

Lee, M.C. 2009. Factors influencing the adoption of internet banking: an integration of TAM and TPB with perceived risk and perceived benefit. Electronic Commerce Research and Applications, 8, 130-141.

Liao, Z. dan Cheung, M.T. 2001. Internet-based e-shopping and consumer attitudes: an empirical study. Information $\mathcal{E}$ Management, 38, 299-306.

Lin, H. dan Wang, Y. 2005. Predicting consumer intention to use mobile commerce in Taiwan. Proceedings of the International Conferences on Mobile Business (ICMB'05), Sydney, Australia.

Luarn, P. dan Lin, H. 2005. Toward an understanding of the behavioral intention to use mobile banking. Computer Human Behavior, 21, 873-891.

Mardiasmo. 2009. Public Sector Accounting (Akuntansi Sektor Publik). Andi Publishing, Yogyakarta.

McCloskey, D.W. 2006. The importance of ease of use, usefulness, and trust to online consumers: an examination of the technology acceptance model with older consumers. Journal of Organizational and End User Computing, 18, 47-65.

McKechnie, S., Winklhofer, H. dan Ennew, C. 2006. Applying the technology acceptance model to the online retailing of financial services. International Journal of Retail $\mathcal{E}$ Distribution Management, 34, 388-410.

Morosan, C. dan Jeong, M. 2008. User's perceptions of two types of hotel reservation web sites. International Journal of Hospitality Management, 27, 284-292.

Rotchanakitumnuai, S. 2013. The governance evidence of e-government procurement. Transforming Government: People, Process and Policy, 7, 309-321.

Straub, D., Limayem, M., Karahanna-Evaristo, E. 1995. Measuring System Usage: Implications for IS Theory Testing. Management Science, 41, 1328-1342.

Sumanjeet, S. 2009. Emergence Of Payment Systems In The Age Of Electronic Commerce: The State Of Art. Global Journal of International Business Research, 2, 17-36. 
Venkatesh, V., dan Davis, F.D. 1996. A Model Of The Antecedents Of Perceived Ease Of Use: Development And Test. Decision Sciences, 27, 451-481.

Venkatesh, V., dan Davis, F.D. 2000. A Theoretical Extension of the Technology Acceptance Model: Four Longitudinal Field Studies. Management Science, 46, 186-204.

$\mathrm{Wu}$, I. dan Chen, J. 2005. An extension of trust and TAM model with TPB in the initial adoption of on-line tax: an empirical study. International Journal of Human-Computer Studies, 62, 784-808.

Yi, M. dan Hwang, Y. 2003. Systems: self-efficacy, enjoyment, learning goal orientation, and the technology acceptance model. International Journal of Human-Computer Studies, 59, 431-449. 